\title{
Conservative Amino Acid Substitution in the Myelin Proteolipid Protein of Jimpymsd Mice
}

\author{
Simonida Gencic and Lynn D. Hudson \\ Laboratory of Viral and Molecular Pathogenesis, National Institute of Neurologic Disorders and Stroke, National Institutes \\ of Health, Bethesda, Maryland 20892
}

\begin{abstract}
The capacity for synthesizing and maintaining a compact myelin sheath is destroyed in a number of inborn errors of myelin metabolism. One class of hypomyelinating mutations, which displays an X-linked pattern of inheritance, is distinguished by marked disturbances in oligodendrocyte differentiation. We have defined the molecular defect in one such mutant that lacks mature oligodendrocytes, the $X$-linked jimpy myelin synthesis deficient $\left(j^{m a d}\right)$ trait in mice. The structure of the gene encoding the most abundant myelin protein, proteolipid protein (PLP), was determined by mapping and partially sequencing genomic clones from jp jad $^{\text {and }}$ wild-type mice. Jpmod mice have a single base change in PLP, a C $\rightarrow$ T transition in exon 6 that would substitute a valine for alanine in both PLP and its alternatively spliced isoform, DM20. The mutation was confirmed by polymerase chain reactionamplifying exon 6 from genomic DNA and then either sequencing the amplified DNA or directly probing exon 6 with oligonucleotides designed to detect a single base mismatch. The conservative amino acid replacement in PLP/DM20 of jp $^{\text {msd }}$ mice results in a pleiotropic phenotype similar to that observed for the allelic mutation jimpy, in which a splicing defect has radically altered the PLP/DM20 protein. The accelerated turnover of oligodendrocytes in both mouse mutants suggests a function for PLP/DM20 in oligodendrocyte differentiation distinct from the role of these proteolipid proteins as structural components of the myelin sheath.
\end{abstract}

The structure of myelinated axons in the CNS depends on 2 types of support cells, the oligodendrocytes that enwrap axons with an extension of their plasma membrane to form a myelin sheath and the Type 2 astrocytes that contact axons between the myelin segments at the nodes of Ranvier (ffrench-Constant et al., 1986; Miller et al., 1989). Both of these cells originate from a bipolar progenitor cell that rapidly differentiates to an oligodendrocyte in the absence of any soluble signals or cell contact (Temple and Raff, 1985). Oligodendrocyte differentiation is disrupted in the jimpy mouse mutant. Despite the ex-

Received Mar. 8, 1989; revised June 22, 1989; accepted June 23, 1989.

We thank Dr. R. Lazzarini for continued support, J. Berndt for excellent technical assistance, Dr. M. K. Wolf for the jpmst mice, Dr. J. Weis for the mouse genomic library, Dr. C. Jordan for computer assistance, P. Kelly for synthetic oligonucleotides, and Drs. M. Dubois-Dalcq and N. Nadon for critical review of the manuscript. S.G. gratefully acknowledges the funding of the Deutsche Forschungsgemeinschaft.

Correspondence should be addressed to Lynn D. Hudson, Laboratory of Viral and Molecular Pathogenesis, National Institute of Neurologic Disorders and Stroke, National Institutes of Health, Bldg. 36, Room 5D04, Bethesda, MD 20892.

Copyright $\odot 1990$ Society for Neuroscience $0270-6474 / 90 / 010117-08 \$ 02.00 / 0$ cessive proliferation of oligodendrocyte progenitors in this X-linked disorder (Privat et al., 1982; Skoff, 1982), few mature oligodendrocytes are present (Kraus-Ruppert et al., 1973; Matthieu et al., 1973; Meier and Bischoff, 1975; Skoff, 1976), and the onset of myelination is accompanied by an unusual degree of oligodendrocyte cell death (Knapp et al., 1986). The other major support cell of the CNS, the astrocyte, displays marked hypertrophy (Skoff, 1976, 1982; Dupouey et al., 1980). The molecular defect in jimpy mice resides in a gene encoding proteolipid protein (PLP), a transmembrane protein of oligodendrocytes that comprises half of the protein of the myelin sheath (Macklin et al., 1987b; Nave et al., 1987b). A single point mutation in a splice site for PLP creates aberrantly spliced PLP transcripts in jimpy mice that would result in an abnormal protein with an unusual cysteine-rich carboxy terminus (Morello et al., 1986; Nave et al., 1986, 1987b; Hudson et al., 1987; Macklin et al., 1987b; Ikenaka et al., 1988). Abnormal PLP has been localized immunocytochemically to the rough endoplasmic reticulum of the few remaining oligodendrocytes in jimpy mice (Roussel et al., 1987), where it is probably targeted for destruction. Myelin sheaths can be assembled by these surviving jimpy oligodendrocytes, but the myelin does not contain PLP (Duncan et al., 1989). Whereas normal myelin consists of concentric membrane layers alternating between the apposition of the extracellular faces of the oligodendrocyte plasma membrane (intraperiod line) and the cytoplasmic faces (major dense line), in jimpy mice the architecture of the spiral is disturbed. Myelin sheaths synthesized by jimpy oligodendrocytes have lost the 2-nm gap characteristic of the intraperiod line (Duncan et al., 1989). The much condensed intraperiod line in PLP-deficient myelin sheaths is consistent with the observation that, in normal oligodendrocytes, the majority of the PLP molecule resides on the extraccllular surface of the plasma membrane, the precursor of the intraperiod line (Hudson et al., 1989b).

The elucidation of the molecular defect in jimpy mice has suggested a function for PLP in the formation of the intraperiod line of myelin. But identifying the lesion in jimpy mice has not clarified why such a catastrophic loss of oligodendrocytes occurs in this mutant. Could the overproduction of an aberrant membrane protein derail all protein trafficking through the rough endoplasmic reticulum? Or could PLP operate in myelinating cells in 2 capacities, 1 as a structural component of the myelin sheath and the other as a molecule necessary for either the development or maintenance of a mature oligodendrocyte.

To define the basis for the pleiotropy exhibited by the mutant PLP gene in jimpy mice, we have analyzed another $\mathrm{X}$-linked myelin synthesis deficiency in mice, jimpy myelin synthesis deficient ( $\mathrm{jp}^{\mathrm{msd}}$ ) mutant mice, which is allelic to jimpy (Eicher and Hoppe, 1973). Jp ${ }^{\text {msd }}$ has been extensivcly charactcrized by 


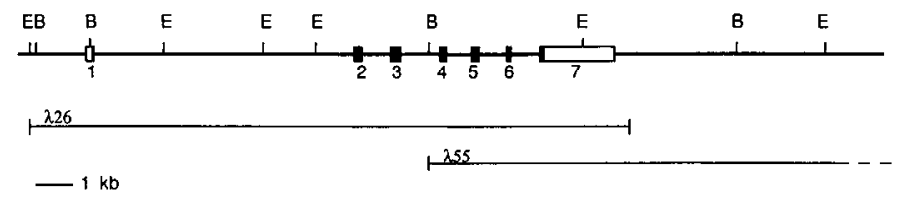

Figure 1. Structure of the murine PLP gene. Exons are numbered 17 , with coding regions shaded; restriction sites include BamHI $(B)$ and EcoRI $(E)$. The positions of the 2 phage clones isolated from a jp misd $^{\text {mat }}$ library are noted by a line.

Billings-Gagliardi and Wolf, who documented the lack of mature oligodendrocytes and other morphological features that mimic the jimpy mutation (Billings-Gagliardi et al., 1980a, b; Billings-Gagliardi and Adcock, 1981; Wolf et al., 1983). When on the same genctic background, jp $^{\text {msd }}$ mice have noticeably more myelin than jimpy mice (Wolf et al., 1983). Residual amounts of myelin proteolipid proteins of normal size can be immunostained from concentrated extracts of jp $\mathrm{p}^{\text {msd }}$ brain (Gardinier and Macklin, 1988). The message for PLP and the alternatively spliced isoform DM20 was not detectably altered in jpmsd mice by RNA protection assays (Hudson et al., 1987). However, mRNA levels for PLP as well as other myelin-specific messages such as MBP were sharply diminished coincident with the marked reduction of mature oligodendrocytes (Hudson et al., 1987; Gardinier and Macklin, 1988). We report here that the PLP gene of jp $^{\text {msd }}$ mice suffers a point mutation that results in a conservative amino acid replacement in PLP.

This work was presented in part at a conference on Neurological Mutations of the Mouse, Jackson Laboratories, Bar Harbor, Maine, September 1988.

\section{Materials and Methods}

Construction and screening of bacteriophage libraries. A murine genomic EMBL3 library constructed from a $B A L B / c$ mouse was obtained from Dr. John Weis and was screened for PLP-containing clones with mouse PLP cDNA probes (Hudson et al., 1987) nick-translated with [ $\left.\alpha^{32} \mathrm{P}\right]-$ dCTP (Amersham). From $10^{6}$ plaques screened, 6 positive clones were mapped in detail and subcloned into $\mathrm{pTZ} 19 \mathrm{R}$ for sequencing of doublestranded plasmid DNA with either Klenow or reverse transcriptase (GEMSEQ; Promega Biotec) as described by the manufacturer. Plasmid subclones containing portions of the wild type (BALB/c) PLP gene included: pLH117, 3.1-kb EcoRI-BamHI fragment containing exons 2 and 3; pLH1 18, 4-kb BamHI-EcoRI fragment containing exons 4-6 and a portion of exon 7; pLH119, 1.5-kb BamHI-BamHI fragment containing portions of exon $l$ and upstream regions (see Fig. $l$ for the positions of the EcoRI and BamHI restriction sites).

Genomic DNA was prepared from livers of $\mathrm{jp}^{\mathrm{msd}}$ mice provided by Dr. M. K. Wolf; these mice were maintained by breeding heterozygous females to $(\mathrm{C} 57 \mathrm{BL} / 6 \mathrm{~J} \times \mathrm{C} 3 \mathrm{H} / \mathrm{HeJ}) \mathrm{F}_{1}$ males. High-molecular-weight $\mathrm{jp}^{\mathrm{msd}}$ DNA was partially digested with Sau3A (New England Biolabs), ligated to BamHI digested EMBL3 arms (Stratagene), and packaged using Gigapack (Stratagene). Of 750,000 plaques screened as above, 11 positive clones were subsequently screened with end-labeled oligonucleotide probes corresponding to each of the 7 exons. Two of these clones $(\lambda 26, \lambda 55)$ were mapped in more detail by cos mapping (Rackwitz et al., 1984); $\lambda 26$ contained the entire PLP locus, as diagrammed in Figure 1. Plasmid subclones of $\lambda 26$ were constructed for sequencing all exons, intron-exon junctions, and flanking regions of the jp ${ }^{\text {misd }}$ PLP gene: pSG 1, 7.8-kb EcoRI-EcoRI fragment containing exons 2-6 and over half of exon 7; pSG2, 3.8-kb EcoRI-EcoRI fragment containing exon 1 and upstream region.

Probing and sequencing PCR-amplified DNA. Genomic or phage DNA corresponding to exon 6 of the PLP gene was amplified by the polymerase chain reaction essentially as described by Erlich and co-workers (Higuchi et al., 1988; Saiki et al., 1988). Each 100- $\mu$ l reaction mixture contained $1 \mu \mathrm{g}$ of genomic DNA in $50 \mathrm{~mm} \mathrm{KCl}, 10 \mathrm{~mm}$ Tris (pH 8.4), $2.5 \mathrm{mM} \mathrm{MgCl}_{2}$, each primer at $1 \mu \mathrm{M}$, each dNTP at $200 \mu \mathrm{M}, 170 \mu \mathrm{g} / \mathrm{ml}$
BSA, and 2 units of TaqI polymerase (Stratagene). The primers, which corresponded to intronic sequences located 50 bases upstream and downstream of exon 6, were prepared on an Applied Biosystems synthesizer. Thirty cycles of amplification were carried out, with each cycle consisting of a $1-\min , 95^{\circ} \mathrm{C}$ denaturation step, followed by a $2-\mathrm{min}$, $55^{\circ} \mathrm{C}$ annealing step, and finally a $70^{\circ} \mathrm{C}$ extension step for $2 \mathrm{~min}$. The 206-bp amplified fragment was separated from primers and unincorporated deoxynucleotides on Centricon 30 filtration units (Amicon).

Following amplification, approximately one-tenth of each reaction was subjected to electrophoresis on composite $3 \% \mathrm{Nu}$-Sieve agarose (FMC)/1\% Seakem nonmodified agarose gels and electrophoretically transferred to nitrocellulose using the low-pH citrate-phosphate buffer as described by Smith et al. (1984). A $40 \times$ stock of transfer buffer of pH 3.0 was prepared by mixing $200 \mathrm{ml}$ of $1 \mathrm{M}$ monobasic sodium phosphate with $55 \mathrm{ml}$ of $1 \mathrm{M}$ citric acid. Prior to transfer, gels were stained with ethidium bromide and photographed under UV light and then the DNA was denatured by treatment with $0.2 \mathrm{M} \mathrm{NaOH}, 0.6 \mathrm{M}$ $\mathrm{NaCl}$ for $30 \mathrm{~min}$. Blots were incubated overnight at $42^{\circ} \mathrm{C}$ in hybridization buffer containing $5 \times$ SSPE, $5 \times$ Denhardt's, $1 \%$ SDS, $100 \mu \mathrm{g} / \mathrm{ml}$ salmon sperm DNA, and $8 \times 10^{6} \mathrm{cpm} / \mathrm{ml}$ of a 19 -mer oligonucleotide phosphorylated with $\left[\lambda^{32} \mathrm{P}\right]-\mathrm{ATP}$ to a specific activity of $2 \times 10^{8} \mathrm{cpm} /$ $\mu \mathrm{g}$. Blots were washed at stringencies designed to detect a single base mismatch as detailed by Conner et al. (1983) and exposed to film.

Amplified fragments were sequenced by the method of Higuchi et al. (1988) using a second set of internal primers phosphorylated with $\left[\gamma^{32}\right.$ P]-ATP (Amersham) by T4 polynucleotide kinase (New England Biolabs) to a specific activity of approximately $2 \times 10^{8} \mathrm{cpm} / \mu \mathrm{g}$. Approximately $0.4 \mathrm{pmol}$ of microconcentrator-purified, amplified DNA was mixed with 3 pmol of end-labeled sequencing primer $(20-\mathrm{mer})$ in $13 \mu \mathrm{l}$ $10 \mathrm{~mm}$ Tris (pH 8.0), $1 \mathrm{~mm}$ EDTA, incubated at $95^{\circ} \mathrm{C}$ for $10 \mathrm{~min}$ to denature the template and then split into 4 tubes corresponding to the 4 termination mixes. The modified T7 DNA polymerase described by Tabor and Richardson (1987) and supplied as Sequenase by U.S. Biochemical was used with the reagents and conditions specified by the manufacturer. After incubation at $37^{\circ} \mathrm{C}$ for $10-15 \mathrm{~min}$, samples were loaded onto $8 \%$ acrylamide (20:1, acrylamide:BIS), $8 \mathrm{~m}$ urea gels in Trisborate-EDTA buffer and electrophoresed at $75 \mathrm{~W}$ for $2 \mathrm{hr}$. Gels were fixed in 10\% methanol, $10 \%$ acetic acid, dried, and exposed to film for $3 \mathrm{hr}$ with an intensifying screen. To eliminate possible errors due to the TaqI polymerase, samples were amplified in duplicate and both samples were sequenced.

\section{Results}

Structure of the PLP gene in jp $p^{m s d}$ mice

Genomic Southern blots revealed no differences in the pattern of bands displayed by $\mathrm{jp}^{\mathrm{msd}}$ mice compared to wild-type mice (data not shown). The PLP locus in $\mathrm{jp}^{\mathrm{msd}}$ mice was mapped in detail with $2 \lambda$ clones, 1 of which $(\lambda 26)$ spanned the entire PLP gene (Fig. 1). The structure of the PLP gene in jp prd $^{\text {mice }}$ was indistinguishable from wild type (Fig. 1; Macklin et al., 1987a). Moreover, the position and sequences of the junctions between introns and exons were identical in $\mathrm{jp}^{\mathrm{msd}}$ and wild-type mice (Fig. 2), eliminating the possibility that a splicing mutation was the defect in $\mathrm{jp}^{\mathrm{msd}}$ mice.

Previous RNAase protection experiments had indicated that the PLP coding region was unaltered in $\mathrm{jp}^{\mathrm{msd}}$ mice, suggesting that these mice may have a mutation in a regulatory site (Hudson et al., 1987). To explore that prospect, a kilobase of upstream region bordering exon 1 was sequenced from $\mathrm{jp}^{\mathrm{msd}}$ and wildtype subclones. This region contains the promoter and several binding sites for nuclear proteins (L. D. Hudson, unpublished observations). Not one base pair differed between jp p $^{\text {sd }}$ and wildtype mice for 883 bp $5^{\prime}$ to exon 1 (Fig. 3).

\section{A point mutation in exon 6 of $\mathrm{jp}^{\text {msd }}$ mice}

Sequencing the entire coding region of PLP in jp prs $^{\text {mice dis- }}$ closed a single base change that would substitute valine for alanine at amino acid 242 (Fig. 4). To dismiss the possibility that the $\mathrm{C} \rightarrow \mathrm{T}$ transition in $\mathrm{jp}^{\mathrm{msd}}$ was due to a cloning artifact, 


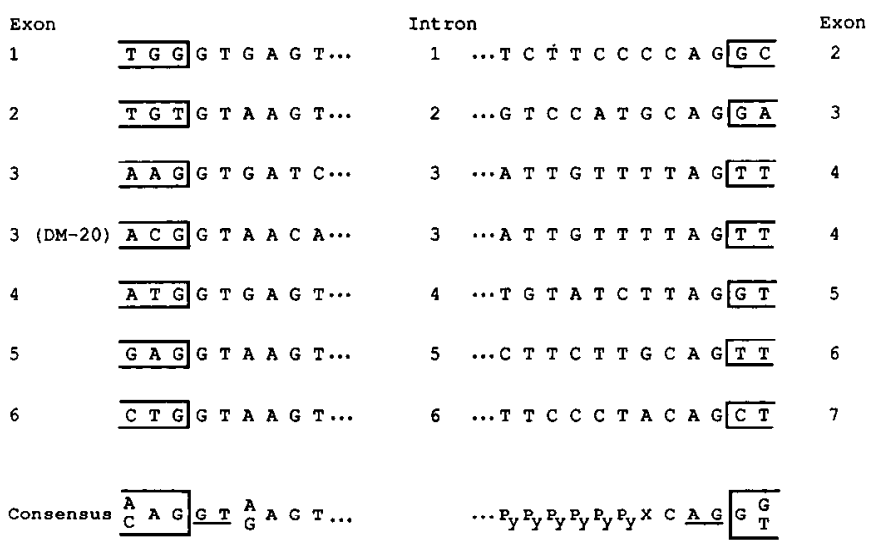

Figure 2. Splice junctions at the murine PLP locus. Exon sequences are boxed and the invariant residues of the consensus sequence underlined. The $\mathrm{jp}^{\mathrm{msd}}$ and wild-type junctions are identical, and differ from the sequence published by Macklin et al. (1987a) for normal mice at 2 positions: 9 bases upstream of the exon 5 acceptor splice, Macklin et al. have an additional $T$ and 2 bases upstream of the exon 6 acceptor splice, an additional $\mathrm{A}$.

plasmid subclones from both $\lambda 26$ and $\lambda 55$ were sequenced. In addition, exon 6 was amplified directly from genomic DNA by the polymerase chain reaction (PCR) and sequenced as shown in Figure 4. The single base change could also be detected without sequencing by using an oligonucleotide probe specific for either the wild-type or jp ${ }^{\text {msd }}$ sequence (Fig. 5). A 19-mer synthetic oligonucleotide corresponding to the $\mathrm{jp}^{\mathrm{msd}}$ sequence hybridized only to PCR-amplified exon 6 from jp ${ }^{\text {rus }}$ DNA (Fig. 5, middle panel, lane 2). Substantially reduced hybridization was observed with this probe for wild-type PCR-amplified DNA due to the centrally located single base mismatch (Fig. 5, middle panel, lane 3). Reciprocal results were observed for the wild-type-specific probe (Fig. 5, right panel, lanes 2 and 3 ).

The $\mathrm{jp}^{\mathrm{msd}}$ strain used in this work is on the genetic background of a cross between 2 inbred lines, $\mathrm{C} 57 \mathrm{BL} / 6 \mathrm{~J}$ and $\mathrm{C} 3 \mathrm{H} / \mathrm{HeJ}$. Since the normal PLP gene structure was deduced from a genomic library that was constructed from a BALB/c mouse, exon $6 \mathrm{DNA}$ from a $(\mathrm{C} 57 \mathrm{BL} / 6 \mathrm{~J} \times \mathrm{C} 3 \mathrm{H} / \mathrm{HeJ}) \mathrm{F}_{1}$ mouse was also ana- lyzed (Figs. 4, 5). No polymorphism is evident in the PLP coding region of these strains of normal mice or in the NIH mice originally used (Hudson et al., 1987) to obtain cDNA clones of PLP.

\section{Discussion}

The PLP gene of jp $^{\text {msd }}$ mice displays a single point mutation, a $\mathrm{C} \rightarrow \mathrm{T}$ transition in exon 6 . This base change was not detected by RNAase protection experiments (Hudson et al., 1987) since a $\mathrm{G}: \mathrm{U}$ base pair is not recognized as a mismatch in these assays. The possibility that this is a secondary mutation arising in the many generations since the $\mathrm{jp}^{\mathrm{msd}}$ mouse was first identified is unlikely. There was no evidence for a regulatory mutation affecting either the synthesis or processing of PLP message. Not only was the sequence of the upstream, putative regulatory region of PLP unchanged (Fig. 3), PLP mRNA was produced at levels commensurate with the number of mature oligodendrocytes surviving in jp $^{\text {msd }}$ mice (Hudson, unpublished observations). The PLP message was polyadenylated and correctly spliced, as indicated by the presence of normal splice junctions (Fig. 2) and an unaltered RNAase protection pattern for both PLP and DM20 transcripts from oligo-dT selected mRNA (Hudson et al., 1987). Moreover, the messages for PLP and DM20 can be translated in vivo in jpms mice, as proteins immunologically indistinct from normal PLP and DM20 comigrated with the authentic proteins on immunoblots of $\mathrm{jp}^{\text {msd }}$ brain homogenates (Gardinier and Macklin, 1988).

The substitution of valine for alanine at position 242 of PLP is a conservative amino acid change that drastically affects oligodendrocyte maturation. The extreme conservation of the PLP gene both between and within species (Fig. 6; discussed in Hudson et al., 1989a) and the presence of alanine at this position in 4 inbred mouse lines (see Results, Hudson et al., 1987; Macklin et al., 1987a; Nave et al., 1987a; Ikenaka et al., 1988), rat (Dautigny et al., 1985; Milner et al., 1985), dog (Nadon et al., 1988), cow (Naismith et al., 1985), and human (Diehl et al., 1986; Puckett et al., 1987) indicate that the valine substitution is not a polymorphism. The site of the valine substitution is in 1 of the $2 \alpha$-helical, hydrophobic domains of PLP that reside on the extracellular face of the oligodendrocyte plasma mem-

\begin{abstract}
сССССССССАACTCTGACTGCTGCTTTCCCAAACGCTCCTICCGTCTCCTTAGCCTCATCTTCACTCTGATGGGAACACTATTTCCTG - 793 GGAAGAGTTTTGACTAGCTGCTTGCCAGTTTGTGATAATGTCTTGTCTCAGAgTTCATTimCCTTGAAAATTGCCTACATGGTCCACTCT -703 GGCCTTTTTGTCCCTTGTGACCTTGGCACAGGTCTIGCCCTCTCCTTTGTATCTCTGTTATCCAAATGTACTCTCATTGCACGTCTGGCT - 613

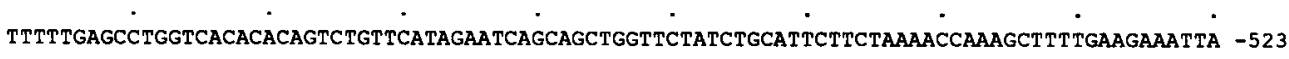

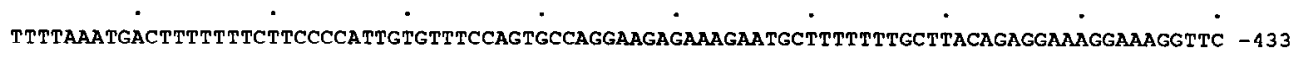

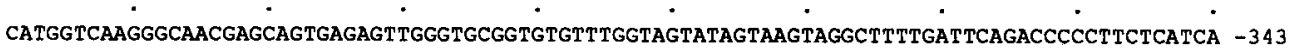

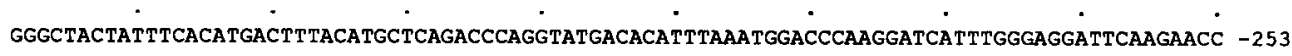

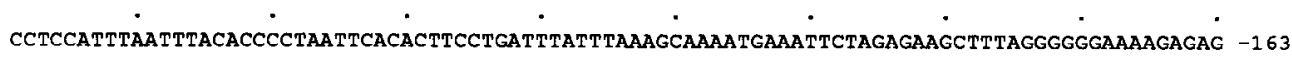

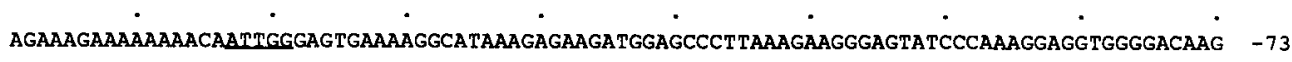

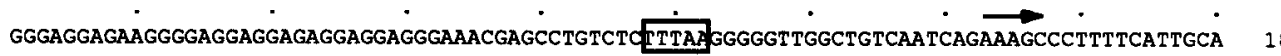

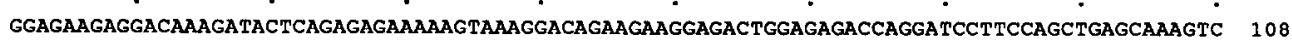
agccgcaAaAcagactagccaAcaggctacatiggagtcagagtgccaiagac atg g Met
\end{abstract}

Figure 3. Upstream region of the murine PLP gene. Exon 1 and 883 bases of upstream sequence are preserved in jp $\mathrm{psd}^{\mathrm{ms}}$ mice. Wild type (BALB/c mouse) was sequenced from pLH119 and mutant ( $j p^{m s d}$ mouse) was sequenced from pSG2; no differences were detectable between the 2 . The TATA box is shown as a boxed region and an inverted CCAAT box is underlined. The transcription initiation site is depicted with an arrow. The initiator methionine, the only amino acid encoded by the first exon, is shown below the ATG codon. 


\section{TCGA TCGA TCGA}

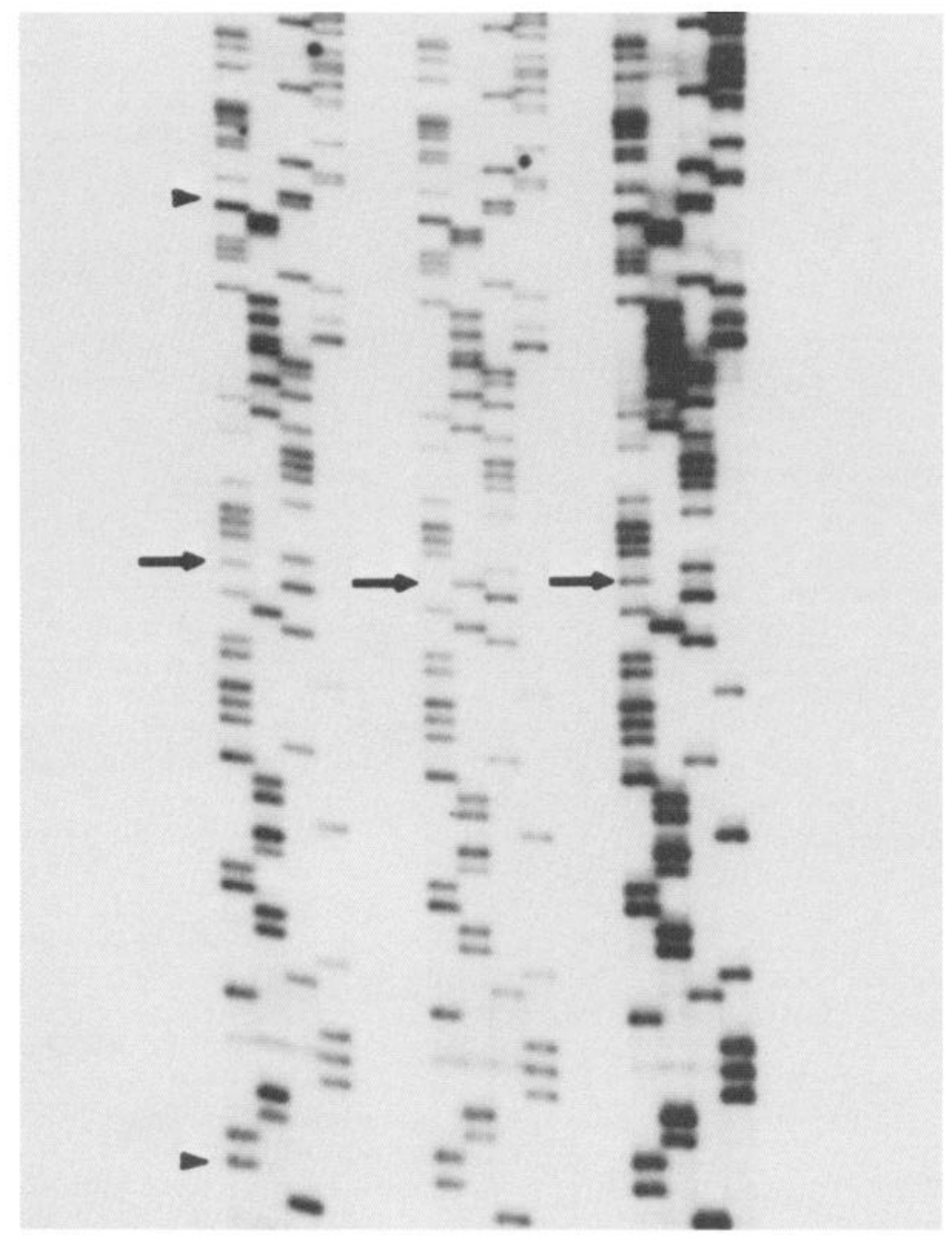

Figure 4. Sequence of PCR-amplified exon 6. Genomic DNA from $\mathrm{jp}^{\mathrm{msd}}$ or wild type $\left(w t ; \mathrm{F}_{1}\right.$ of $\mathrm{C} 57 \mathrm{BL} / 6 \mathrm{~J} \times \mathrm{C} 3 \mathrm{H} /$ $\mathrm{HeJ}$ ) was amplified and sequenced, as was phage DNA isolated from $\lambda 55$, the phage containing exons 4-7 of the jp msd $^{\text {msd }}$ PLP gene. $\Delta$, limits of exon $6 ; \rightarrow$, position of the $\mathrm{C} \rightarrow \mathrm{T}$ base change in $\mathrm{jp}^{\mathrm{msd}}$. The resulting valine at position 242 in exon 6 is noted in parentheses below the wild-type sequence of exon 6 .
$\mathrm{T}$

TTC CAA ATG ACC TTC CAC CTG TTT ATT GCT GCG

Phe Gln Met Thr Phe His Leu Phe Ile Ala Ala

(Val)

TTT GTG GGT GCT GCG GCC ACA CTA GTT TCC CTG

Phe Val Gly Ala Ala Ala Thr Leu Val Ser Leu brane (Fig. 6). These domains have been proposed to participate in homophilic interactions that may be critical to the formation of a compact myelin sheath (Hudson et al., 1989b). An introduced valine residue, which would be present both in the PLP protein and in DM20, the other isoform of the PLP locus, may interrupt these interactions although the $\alpha$-helical structure should not be disrupted (Fig. 6). Another valine substitution that dramatically alters the structure of a membrane protein has recently been constructed by Flavell and co-workers, who found that replacing an aspartate with valine converted the cell-surface glycoprotein Qa-2 from a phosphatidylinositol anchored form into an integral membrane protein (Waneck et al., 1988).

DM20 is identical to PLP except for the deletion of residues 116-150 (Trifilieff et al., 1986; Hudson et al., 1987; Nave et al., 1987a). Its structure probably resembles that of PLP, because the deletion leaves intact the 4 hydrophobic $\alpha$-helices that give 


\section{jpmsd}

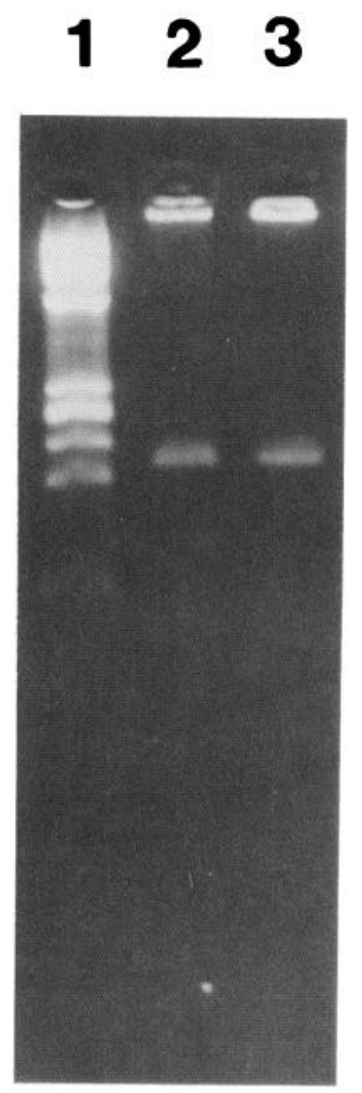

\section{wt}

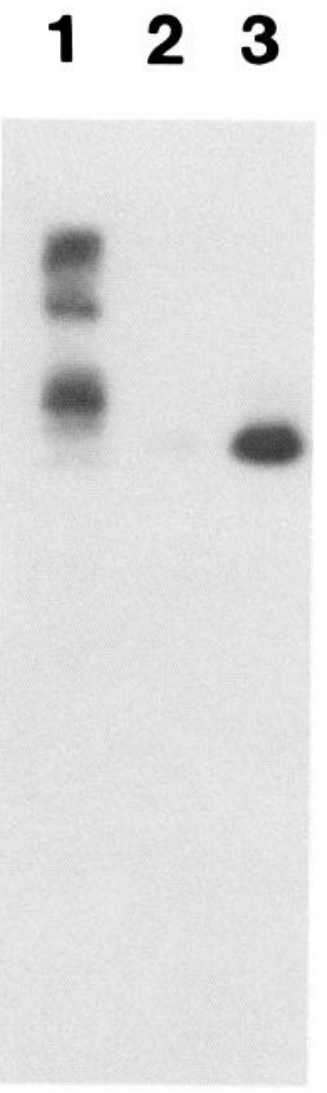

Figure 5. Detection of a single base change in PCR-amplified DNA. The ethidium bromide-stained gel is shown in the far left panel, with the resultant Southern blot probed with the $\mathrm{jp}^{\mathrm{msd}}$ oligonucleotide (center) or the wild-type oligonucleotide in the far right. Lane 1 , $\phi$ X174-Hae III and $\lambda$ HindIII markers; lane 2, PCR-amplified $\mathrm{jp}^{\mathrm{msd}}$ genomic DNA; lane 3, PCR-amplified genomic DNA from a $(\mathrm{C} 57 \mathrm{BL} / 6 \mathrm{~J} \times \mathrm{C} 3 \mathrm{H} / \mathrm{HeJ}) \mathrm{F}_{\text {, }}$ mouse. The sequence of the 19-mer probes is shown below the panels, with arrows pointing to the difference between $\mathrm{jp}^{\mathrm{msd}}$ and wild type. The noncoding strand was chosen for the $\mathrm{jp}^{\mathrm{msd}}$ probe to maximize the mismatch between it and wild type (A/C mismatch as shown vs a $G / T$ pairing if the coding strand was used).

\section{jpmsd: $\quad 3^{\prime}$-AATAACGACACAAACACCC-5'}

PLP much of its character (Laursen et al., 1984; Stoffel et al., 1984; Hudson et al., 1989b). However, DM20 can be selectively extracted from myelin using methylene chloride : methanol (3: 7) without affecting PLP (Skalidis et al., 1986), which suggests that DM20 is structurally distinct from PLP. Luu and co-workers have described other physical parameters, including the poor solubility of DM20 relative to PLP, which may have biased earlier estimations of the abundance of this alternatively spliced isoform (Van Dorsselaer et al., 1987). DM20 is manifest in early development in vast excess of PLP(DM20:PLP, 12:1); in adults, DM20 remains an abundant myelin proteolipid protein although the DM20:PLP ratio becomes inverted (0.5-0.8:1) (Van Dorsselaer et al., 1987). An intriguing aspect of the $\mathrm{jp}^{\mathrm{msd}} \mathrm{mu}-$ tation is the observation that although the point mutation is present in both PLP and DM20 transcripts (Fig. 4), DM20 protein is not as dramatically reduced as PLP (Gardinier and Macklin, 1988). A similar phenomenon was noted in the shaking pup, another PLP mutation that results in an amino acid substitution in both PLP and DM20 (Nadon et al., 1988). DM20 and PLP protein were expressed in approximately equal, albeit greatly reduced amounts in shaking pup, while the ratio in control animals was 0.06 (Yanagisawa et al., 1987). The appearance of a DM20:PLP ratio characteristic of very young, normal animals in these mutant models hints at the possibility that the few surviving oligodendrocytes in $\mathrm{jp}^{\mathrm{msd}}$ and shaking pup are blocked at an early stage of oligodendrocyte maturation. 
Figure 6. Structure of normal and mutant PLP. The model for the orientation of PLP in the oligodendrocyte plasma membrane is adapted from Hudson et al. (1989b). The amino $\left(\mathrm{NH}_{2}\right)$ and carboxyl $(\mathrm{COOH})$ termini reside on the extracellular face of the plasma membrane; the 4 extremely hydrophobic regions $(A-D)$ pictured as $\alpha$-helices may interact intramolecularly ( $A$ with $B$; $C$ with $D$ ) as shown or intermolecularly (not pictured). The valine substitution present in $\mathrm{jp}^{\mathrm{msd}}$ mice at position 242 within the $D$ region $\alpha$-helix is noted with an arrow. The amino acids that distinguish dog (valine instead of isoleucine at position 160) and cow PLP (alanine instead of phenylalanine at position 188 , threonine instead of serine at position 198) from mouse, rat, and human PLP are noted by dotted circles. No amino acid polymorphism has been found within a species. $I-V I$ denote the regions corresponding to the synthetic peptides used to generate antibodies to specific portions of PLP (Hudson et al., 1989b).

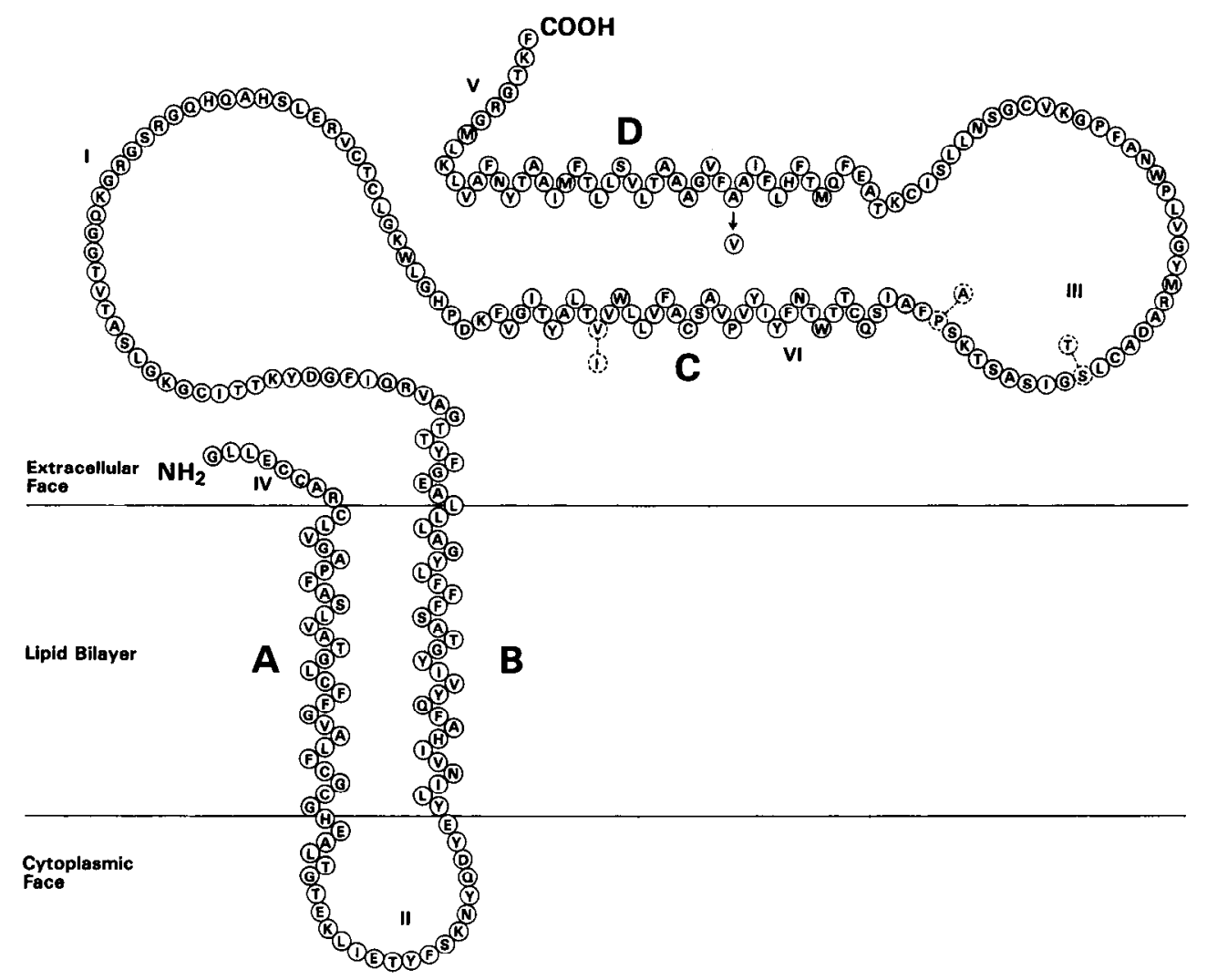

How can a mutation in one of the structural proteins of the myelin sheath disrupt oligodendrocyte differentiation? Certainly not by preventing an oligodendrocyte from assembling a compact myelin sheath, since shiverer mice, which suffer a deletion in another abundant structural myelin protein (myelin basic protein, MBP) (Roach et al., 1985; Molineaux et al., 1986), still manage to produce mature oligodendrocytes that synthesize abnormal myelin (Matthieu et al., 1981; Frail and Braun, 1985). Nor is the specter of a lethal PLP protein a likely possibility, for several reasons. First, while the jimpy mutation would create a grossly abnormal PLP ( $20 \%$ cysteine residues encoded by the frame-shifted terminal exon) that at the high levels produced in oligodendrocytes could potentially disrupt protein processing (Hudson et al., 1987), it is unlikely that the distinct single amino acid substitutions of PLP in jp ${ }^{\text {msd }}$ (Fig. 4), shaking pup (Nadon et al., 1988), and Pelizaeus-Merzbacher disease (Gencic et al., 1989; Hudson et al., 1989a) could wreak such havoc. Second, cultured or transplanted jimpy oligodendrocytes can be induced to synthesize myelin (Gumpel et al., 1987; Bartlett et al., 1988), which suggests that despite the continued production of mutant PLP (Roussel et al., 1987), jimpy oligodendrocytes can attempt myelination when presented with the proper signals. We have proposed that PLP and its alternatively spliced counterpart (DM20) have 2 distinct functions in myelinating cells (Hudson et al., 1987; Puckett et al., 1987). As the major protein of the myelin sheath, PLP/DM20 must play a structural role that includes maintaining the integrity of the intraperiod line where the bulk of the protein is located (Hudson et al., 1989b). In jimpy mice, the absence of PLP/DM20 is correlated with a much reduced intraperiod line (Duncan et al., 1989). But perhaps more important to the oligodendrocyte is the role PLP/DM20 must assume in mediating oligodendrocyte differentiation. As mem- brane-bound proteins with the majority of the molecule located on the extracellular surface of the oligodendrocyte plasma membrane (Hudson et al., 1989b), PLP/DM20 are suitably located for signaling or receiving signals from surrounding astrocytes or target neurons.

Both the time course and the amount of PLP/DM20 expression required for a differentiation function are likely to differ from those needed for the assembly of a myelin sheath. The role of PLP/DM20 in oligodendrocyte differentiation would precede myelination and would not demand the great quantities of protein required for myelination. Indeed, transcripts originating from the PLP locus are detectable in mouse brain at day 3 (Gardinier et al., 1986), well before the onset of myelination. Moreover, analysis of another putative PLP mutation, the myelin-deficient (MD) rat, has revealed that MD rat optic nerve cultures contain normal numbers of $0-2 \mathrm{~A}$ progenitors that differentiate into oligodendrocytes faster than controls (Zeller et al., 1989). In these cultures, cell types can be distinguished by their reactivity to an $\mathrm{A}_{2} \mathrm{~B}_{5}$ antibody, which recognizes specific gangliosides on the surface of the $0-2 \mathrm{~A}$ progenitor cells, and galactocerebroside (GC) antibody, which binds to the surface of young and mature oligodendrocytes. The effect of the lack of PLP/DM20 is evident at early stages of oligodendrocyte development in MD cultures, since the precursor cell $\left(\mathrm{A}_{2} \mathrm{~B}_{5}{ }^{+}, \mathrm{GC}^{+}\right)$, the intermediate between the $0-2 \mathrm{~A}$ progenitor $\left(\mathrm{A}_{2} \mathrm{~B}_{5}{ }^{+}, \mathrm{GC}^{-}\right)$and the oligodendrocyte $\left(\mathrm{A}_{2} \mathrm{~B}_{5}{ }^{-}, \mathrm{GC}^{+}\right)$, was reduced in numbers at the expense of the more differentiated $\mathrm{GC}^{+}$cell (Zeller et al., 1989). These results are consistent with the notion that $0-2 A$ progenitor cells rapidly and constitutively differentiate into oligodendrocytes in the absence of signals (Temple and Raff, 1985). In this case, the inability of PLP/DM20-deficient cells to signal or receive signals might hasten their terminal differentiation. 
A second function for PLP was also indicated by the curious expression of this protein in glial cells of the PNS (Puckett et al., 1987). Schwann cells synthesize PLP but exclude it from their myelin sheaths. Even nonmyelinating Schwann cells, which do not produce the myelin proteins that comprise a sheath, feature cytoplasmic PLP (Ono et al., 1989). This seemingly normal PNS of jp ${ }^{\text {msd }}$ mice (Billings-Gagliardi and Adcock, 1981) is difficult to reconcile with a function for PLP in Schwann cells. Nonetheless, PLP's participation in glial cell maturation in the PNS may be complemented by another Schwann-specific protein that can partially substitute for PLP in $\mathrm{jp}^{\mathrm{msd}}$ Schwann cells. Such a scenario ensues when another abundant myelin protein, $\mathrm{MBP}$, is missing. MBP is normally incorporated into both CNS and PNS myelin sheaths. In the shiverer mutation, the absence of MBP leaves oligodendrocytes with loosely wrapped myelin sheaths that lack a major dense line, while Schwann cells appear to employ other basic proteins to assemble myelin that is nearly indistinguishable from normal (Kirschner and Ganser, 1980).

The dual functions of the major myelin proteolipid proteins may mirror the alternative splicing at the PLP locus, which generates both PLP and DM20 transcripts. By analogy to other alternatively spliced genes (reviewed by Breitbart et al., 1987), PLP and DM20 may perform distinct roles in myelinating cells. The early appearance of DM20 recommends this isoform for the differentiation function of the myelin proteolipid protein. Whether DM20 is the molecule mediating oligodendrocyte maturation can now be addressed with the technology of transgenic mice.

\section{References}

Bartlett, W. P., P. E. Knapp, and R. B. Skoff (1988) Glial conditioned medium enables jimpy oligodendrocytes to express properties of normal oligodendrocytes: Production of myelin antigens and membranes. Glia 1: 253-259.

Billings-Gagliardi, S., and L. H. Adcock (1981) Hypomyelinated mutant mice IV. Peripheral myelin in jp ${ }^{\text {msd. }}$. Brain Res. 225: 309-317.

Billings-Gagliardi, S., L. H. Adcock, and M. K. Wolf (1980a) Hypomyelinated mutant mice: Description of $\mathrm{jp}^{\mathrm{msd}}$ and comparison with jp and qk on their present genetic backgrounds. Brain Res. 194: 325338.

Billings-Gagliardi, S., L. H. Adcock, G. B. Schwing, and M. K. Wolf (1980b) Hypomyelinated mutant mice II. Myelination in vitro. Brain Res. 200: 135-150.

Breitbart, R. E., A. Andreadis, and B. Nadal-Ginard (1987) Alternative splicing: A ubiquitous mechanism for the generation of multiple protein isoforms from single genes. Annu. Rev. Biochem. 56: 467-495.

Conner, B. J., A. Reyes, C. Morin, K. Itakura, R. Teplitz, and R. Wallace (1983) Detection of sickle cell $\beta^{\mathrm{s}}$-globin allele by hybridization with synthetic oligonucleotides. Proc. Natl. Acad. Sci. USA 80: 278-282.

Dautigny, A., P. M. Alliel, L. d'Avriol, D. Pham Dinh, J.-L. Nussbaum, F. Galibert, and P. Jolles (1985) Molecular cloning and nucleotide sequence of a cDNA clone coding for rat brain myelin proteolipid. FEBS Lett. 188: 33-36.

Diehl, H. J., M. Schaich, R.-M. Budzinski, and W. Stoffel (1986) Individual exons encode the integral membrane domains of human myelin proteolipid protein. Proc. Natl. Acad. Sci. USA 83: 98079811.

Duncan, I. D., J. P. Hammang, S. Goda, and R. H. Quarles (1989) Myelination in the jimpy mouse in the absence of proteolipid protein. Glia 2: 148-154.

Dupouey, P., C. V. Lucas, D. Gomes, and C. Jacque (1980) Immunohistochemical localization of the myelin basic protein and of the glial fibrillary acidic protein: Comparative study in normal, quaking, and jimpy mice. J. Neurosci. Res. 5: 387-398.

Eicher, E. M., and P. C. Hoppe (1973) Use of chimeras to transmit lethal genes in the mouse and to demonstrate allelism of the $2 \mathrm{X}$-linked male lethal genes jp and jp ${ }^{\mathrm{msd}}$. J. Exp. Zool. 183: 181-184.
ffrench-Constant, C., R. H. Miller, J. Kruse, M. Schachner, and M. C. Raff (1986) Molecular specialization of astrocyte processes at nodes of Kanvier in rat optic nerve. J. Cell Biol. 102: 844-852.

Frail, D. E., and P. E. Braun (1985) Abnormal expression of the myelin associated glycoprotein in the central nervous system of dysmyelinating mutant mice. J. Neurochem. 45: 1071-1075.

Gardinier, M. V., and W. B. Macklin (1988) Myelin proteolipid protein gene expression in jimpy and jimpymsd mice. J. Neurochem. 51 : 360-369.

Gardinier, M. V., W. B. Macklin, A. J. Diniak, and P. L. Deininger (1986) Characterization of myelin proteolipid mRNAs in normal and jimpy mice. Mol. Cell. Biol. 6: 3755-3762.

Gencic, S., D. Abuelo, M. Ambler, and L. D. Hudson (1989) PelizaeusMerzbacher disease: An X-linked neurologic disorder of myelin metabolism with a novel mutation in the gene encoding proteolipid protein. J. Hum. Gen. 45: 435-442.

Gumpel, M., F. Lachapelle, M. Baulac, A. Baron van Evercooren, C. Lubetzki, A. Gansmuller, P. Lombrail, C. Jacque, and N. Baumann (1987) Myelination in the mouse by transplanted oligodendrocytes. In Glial and Neuronal Communication in Development and Regeneration, H. H. Althaus and W. Seifert, eds., pp. 819-830, SpringerVerlag, Berlin.

Higuchi, R., C. von Beroldingen, G. Sensabaugh, and H. Erlich (1988) DNA typing from single hairs. Nature 332: 543-546.

Hudson, L. D., J. Berndt, C. Puckett, C. A. Kozak, and R. A. Lazzarini (1987) Aberrant splicing of proteolipid protein mRNA in the dysmyelinating jimpy mouse. Proc. Natl. Acad. Sci. USA 84: 1454-1458.

Hudson, L. D., C. Puckett, J. Berndt, J. Chan, and S. Gencic (1989a) Mutation of the proteolipid protein (PLP) gene in a human X-linked myelin disorder. Proc. Natl. Acad. Sci. USA 86: 8128-8131.

Hudson, L. D., V. L. Friedrich, T. Behar, M. Dubois-Dalcq, and R. A. Lazzarini (1989b) The initial events in myelin synthesis: Orientation of proteolipid protein in the plasma membrane of cultured oligodendrocytes. J. Cell Biol. 109: 717-727.

Ikenaka, K., T. Furuichi, Y. Iwasaki, A. Moriguchi, H. Okano, and K. Mikoshiba (1988) Myelin proteolipid protein gene structure and its regulation of expression in normal and jimpy mutant mice. J. Mol. Biol. 199: 587-596.

Kirschner, D. A., and A. L. Ganscr (1980) Compact myelin exists in the absence of basic protein in the shiverer mutant mouse. Nature 283: 207-210.

Knapp, P. E., R. P. Skoff, and D. W. Redstone (1986) Oligodendroglial cell death in jimpy mice: An explanation for the myelin deficit. J. Neurosci. 6: 2813-2822.

Kraus-Ruppert, R., N. Herschkowitz, and S. Furst (1973) Morphological studies on neuroglia cells in the corpus callosum of the jimpy mutant mouse. J. Neuropathol. Exp. Neurol. 32: 197-203.

Laursen, R. A., M. Samiullah, and M. B. Lees (1984) The structure of bovine brain myelin proteolipid and its organization in myelin. Proc. Natl. Acad. Sci. USA 81: 2912-2916.

Macklin, W. B., C. W. Campagnoni, P. L. Deininger, and M. V. Gardinier (1987a) Structure and expression of the mouse myelin proteolipid protein gene. J. Neurosci. Res. 18: 383-394.

Macklin, W. B., M. V. Gardinier, K. D. King, and K. Kampf (1987b) An $A G \rightarrow$ GG transition at a splice site in the myelin proteolipid protein gene in jimpy mice results in the removal of an exon. FEBS Lett. 223: 417-421.

Matthieu, J. M., S. Widmer, and H. Herschkowitz (1973) Jimpy, an anomaly of myelin maturation. Biochemical study of myelination phases. Brain Res. 55: 403-412.

Matthieu, J. M., H. Grinalski-Winkelmann, and C. Jacque (1981) Similarities and dissimilarities between two myelin deficient mice, shiverer and mld. Brain Res. 214: 219-222.

Meier, C., and A. Bischoff (1975) Oligodendroglial cell development in jimpy mice and controls, and electron-microscopic study in optic nerve. J. Neurol. Sci. 26: 5517-5528.

Miller, R. H., B. P. Fulton, and M. C. Raff (1989) A novel type of glial cell associated with nodes of Ranvier in rat optic nerve. Eur. $J$. Neurosci. 1: 172-180.

Milner, R. J., C. Lai, K.-A. Nave, D. Lenoir, J. Ogata, and J. G. Sutcliffe (1985) Nucleotide sequences of two mRNAs for rat brain myelin proteolipid protein. Cell 42: 931-939.

Molineaux, S., H. Engh, F. deFerra, L. Hudson, and R. Lazzarini (1986) Recombination within the myelin basic protein gene created the dysmyelinating shiverer mouse mutation. Proc. Natl. Acad. Sci. USA 83: 7542-7546. 
Morello, D., A. Dautigny, D. Pham-Dinh, and P. Jolles (1986) Myelin proteolipid protein (PLP and DM20) transcripts are deleted in jimpy mutant mice. EMBO J. 5: 3489-3493.

Nadon, N., I. Duncan, and L. Hudson (1988) Molecular analysis of the shaking pup mutation. J. Neurosci. 14: 829A.

Naismith, A. L., E. Hoffman-Chudzik, L.-C. Tsui, and J. R. Riordan (1985) Study of the expression of myelin proteolipid protein (lipophilin) using a cloned complementary DNA. Nucl. Acids Res. 13: 7413-7425.

Nave, K. A., C. Lai, F. Bloom, and R. J. Milner (1986) Jimpy mutant mouse: A 74-base deletion in the mRNA for myelin proteolipid protein and evidence for a primary defect in RNA splicing. Proc. Natl. Acad. Sci. USA 83: 9264-9268.

Nave, K. A., C. Lai, F. Bloom, and R. Milner (1987a) Splice site selection in the proteolipid protein (PLP) gene transcript and primary structure of the DM-20 protein of central nervous system myelin. Proc. Natl. Acad. Sci. USA 84: 5665-5669.

Nave, K. A., F. E. Bloom, and R. J. Milner (1987b) A single nucleotide difference in the gene for myelin proteolipid protein defines the jimpy mutation in mouse. J. Neurochem. 49: 1873-1877.

Ono, K., V. Friedrich, L. Hudson, R. Lazzarini, and M. Dubois-Dalcq (1989) The unexpected expression of the major CNS myelin protein, proteolipid protein, in Schwann cells in vivo and in vitro. In Proceedings of the Second International Conference on Charcot-Marie Tooth Disease (in press).

Privat, A., J. Valat, F. Lachpelle, N. Baumann, and J. Fulcrand (1982) Radioautographic evidence for the protracted proliferation of glial cells in the central nervous system of jimpy mice. Dev. Brain Res. 2: $411-416$.

Puckett, C., L. Hudson, K. Ono, V. Friedrich, J. Benecke, M. DuboisDalcq, and R. A. Lazzarini (1987) Myelin specific proteolipid protein is expressed in myelinating Schwann cells but not incorporated into myelin sheaths. J. Neurosci. Res. 18: 511-518.

Rackwitz, H.-R., G. Zehetner, A.-M. Frischauf, and H. Lehrach (1984) Rapid restriction mapping of DNA cloned in lambda phage vectors. Gene 30: 195-200.

Roach, A., N. Takahashi, D. Pravtcheva, F. Ruddle, and L. Hood (1985) Chromosomal mapping of the mouse myelin basic protein gene and structure and transcription of the partially deleted gene in Shiverer mutant mice. Cell 42: 149-155.

Roussel, G., N. M. Neskovic, E. Trifilieff, J.-C. Artault, and J.-L. Nussbaum (1987) Arrest of proteolipid transport through the golgi apparatus in jimpy brain. J. Neurocytol. 10: 195-204.
Saiki, R. K., D. H. Gelfand, S. Stoffel, S. Scharf, R. Higuchi, G. T. Horn, K. B. Mullis, and H. A. Erlich (1988) Primer-directed enzymatic amplification of DNA with a thermostable DNA polymerase. Science 239: 487-491.

Skalidis, G., E. Trifilieff, and B. Luu (1986) Selective extraction of the DM-20 brain proteolipid. J. Neurochem. 46: 297-299.

Skoff, R. P. (1976) Myelin deficit in the jimpy mouse may be due to cellular abnormalities in astroglia. Nature 264: 560-562.

Skoff, R. (1982) Increased proliferation of oligodendrocytes in hypomyelinated mouse mutant-Jimpy. Brain Res. 248: 19-31.

Smith, M. R., C. S. Devine, S. M. Cohn, and M. W. Lieberman (1984) Quantitative electrophoretic transfer of DNA from polyacrylamide or agarose gels to nitrocellulose. Anal. Biochem. 137: 120-124.

Stoffel, W., H. Hillen, W. Schroder, and R. Deutzmann (1983) The primary structure of bovine brain myelin lipophilin (proteolipid apoprotein). Hoppe-Seyler's Z. Physiol. Chem. 364: 1455-1466.

Tabor, S., and C. C. Richardson (1987) DNA sequence analysis with a modified bacteriophage T7 DNA polymerase. Proc. Natl. Acad. Sci. ISSA 84: 4767-4771.

Temple, S., and M. C. Raff (1985) Differentiation of a bipotential glial progenitor cell in single cell microculture. Nature 313: 223-225.

Trifilieff, E., B. Luu, J. L. Nussbaum, G. Roussel, A. Espinosa de los Monteros, J. M. Sabatier, and J. Van Rietschoten (1986) A specific immunological probe for the major myelin proteolipid. Confirmation of a deletion in DM20. FEBS Lett. 198: 235-237.

Van Dorsselaer, A. V., R. Nebhi, O. Sorokine, P. Schindler, and B. Luu (1987) The DM-20 proteolipid is a major brain protein. It is synthesized earlier in fetal life than the major myelin proteolipid (PLP). C. R. Acad. Sci. Paris 305(III): 555-560.

Waneck, G. L., M. E. Stein, and R. A. Flavell (1988) Conversion of a PI-anchored protein to an integral membrane protein by a single amino acid mutation. Science 241: 697-699.

Wolf, M. K., G. B. Kardon, L. H. Adcock, and S. Billings-Gagliardi (1983) Hypomyelinated mutant mice, V. Relationship between jp and $\mathrm{jp}^{\mathrm{msd}}$ re-examined on identical genetic backgrounds. Brain Res. 271: $121-129$

Yanagisawa, K., J. R. Moller, I. D. Duncan, and R. H. Quarles (1987) Disproportional expression of proteolipid protein and DM-20 in the $\mathrm{X}$-linked, dysmyelinating shaking pup mutant. J. Neurochem. 49: 1912-1917.

Zeller, N. K., M. Dubois-Dalcq, and R. A. Lazzarini (1989) Myelin protein expression in the myelin deficient rat brain and cultured oligodendrocytes. J. Mol. Neurosci. (in press). 